\title{
THE USE OF MECHANICAL AERATION AND ITS EFFECTS ON WATER MASS
}

\author{
SIPAÚBA-TAVARES, L. H., FREITAS, A. M. and BRAGA, F. M. S. \\ Centro de Aqüicultura, Unesp, Rodovia Carlos Tonanni, km 05, Jaboticabal, \\ CEP 14870-000, Jaboticabal, SP, Brasil \\ Correspondence to: Lúcia H. Sipaúba-Tavares, Centro de Aqüicultura, Unesp, Rodovia Carlos Tonanni, \\ km 05, CEP 14870-000, Jaboticabal, SP, Brasil \\ Received May 05, 1998 - Accepted August 03, 1998 - Distributed February 01, 1999
}

(With 4 figures)

\begin{abstract}
Due to the increasing use of artificial aerators in fish ponds, and to the lack of studies on this subject, this work studied some of the aspects associated with their use. The influence of a diffuser type aerator (AR 120) on the biotic and abiotic variables was evaluated in a fish pond. Three points of the pond were marked for the taking of samples: 5, 10 and $23 \mathrm{~m}$ from the aerator. Samples were taken every day for 15 consecutive days: 5 days before the use of the aerator, 5 days with the aerator functioning and 5 days with it not functioning. The limnological variables studied did not show significant differences $(\mathrm{P}>0.05)$ when the three sampling points were compared, but regarding the use of the aerator, variables such as water temperature, transparency, $\mathrm{pH}$, dissolved oxygen, bicarbonate, free $\mathrm{CO}_{2}$, total phosphorus, orthophosphate, ammonia nitrate and nitrite concentrations showed significant differences $(\mathrm{P}<0.05)$ when the water was mechanically agitated. There were no significant differences $(\mathrm{P}>0.05)$ with the use of the aerator regarding conductivity, alkalinity, total $\mathrm{CO}_{2}$ and chlorophyll a values. The phytoplanktonic community suffered as a direct influence of the aerator $(\mathrm{P}<0.05)$. The community was dominated by Chlorophyta, representing more than $70 \%$ of the total organisms present, followed by Cyanophyta and Chrysophyta which tended to increase in number after the use of the aerator. This probably occurred because these groups adapt quickly to changes in the environment.
\end{abstract}

Key words: mechanical aeration, limnological characteristics, pond.

\section{RESUMO}

\section{Utilização da aeração mecânica e seu efeito na massa de água}

Devido ao crescente aumento do uso de aeradores artificiais em sistema de cultivo de peixes e à carência de estudos nesta área, este trabalho avaliou a influência de um aerador tipo "propeller diffuser" (AR 120) nas variáveis bióticas e abióticas em um viveiro de engorda de peixe. Foram demarcados três pontos de coleta localizados a 5, 10 e $23 \mathrm{~m}$ de distância do aerador, durante 15 dias consecutivos, sendo 5 dias antes do uso do aerador, 5 dias com o aerador ligado e 5 dias com o aerador desligado. As variáveis limnológicas estudadas não apresentaram diferenças significativas $(P>0,05)$ entre os três pontos de coleta, porém, em relação ao uso do aerador, variáveis como temperatura, transparência, $\mathrm{pH}$, oxigênio dissolvido, bicarbonato, $\mathrm{CO}_{2}$ livre, fósforo total, ortofosfato, amônia, nitrato e nitrito diferiram significativamente $(\mathrm{P}<0,05)$ com a agitação mecânica da água. Já a condutividade, alcalinidade, $\mathrm{CO}_{2}$ total e clorofila a não apresentaram diferenças significativas $(\mathrm{P}>0,05)$ com o uso do aerador. A comunidade fitoplanctônica sofreu influência direta do aerador $(\mathrm{P}<0,05)$, dominada pelas Chlorophyta, representando mais de $70 \%$ do total de organismos presentes, seguidas das Cyanophyta e Chrysophyta, porém estas últimas tenderam a aumentar após o uso do aerador, uma vez que estes grupos se adaptam rapidamente às mudanças do ambiente.

Palavras-chave: aeração mecânica, variáveis limnológicas, viveiros. 


\section{INTRODUCTION}

With the increasing demand for fish production as a source of food, the knowledge of management techniques, in systems with high densities of fish and high feeding rates, has been of great importance in making intensive and semi-intensive fish farming feasible.

The need for reasonably high production rates, requiring reasonable quantities of food and nutrients to be added to the environment, and the cultivation of small animals in high densities can quickly deteriorate water quality if improperly managed.

This is because the limnological characteristics of ponds are highly dynamic (Sipaúba-Tavares \& Moreno, 1994).

The two techniques most widely used in aquaculture to elevate production rates, as well as to conserve environmental conditions of cultivation, are continuous water flow and an increase in dissolved oxygen levels in the aquatic environment, by way of artificial aeration of the system (Hopkins et al., 1993).

According to Parker \& Suttle (1987), water circulation as well as the aeration of fish ponds have been responsible for an increase in primary productivity, reducing stratification, and causing greater soluble nutrient availability, decreasing organic accumulation at the bottom and, consequently, increasing fish production. According to Avnimelech et al. (1992), ponds without water circulation and without a supplementary aeration mechanism, show higher concentrations of organic nitrogen, ammonia and nitrate.

Of the several types of fish pond aerators available on the market, the paddle wheel and the propeller diffuser aerators are the most widely used. The amount of supplementary aeration given will depend on fish density and on the level of nutrients in the pond, but at least $2.0 \mathrm{kw} / \mathrm{ha}(1 \mathrm{HP} / \mathrm{acre})$ should be used when feeding levels are between 30 and $50 \mathrm{~kg} / \mathrm{ha}$ per day. Above these levels, the amount should be two to three times greater (Boyd, 1993).

In Brazil, the growth of fish farming has increased the demand for these kind of aerators, which have assured an increase in productivity rates in fish cultivation ponds, but until now nothing was done to evaluate the effectiveness of this equipment. Fish farming viability is directly associated to management and control of environmental conditions that allow an income that should be compatible to the investment. This way, it is not enough to build good low cost ponds. To obtain high productivity rates it is necessary that the quantity and quality of the water used, the fish density, the species cultivated and their feeding be adequate.

Keeping this in mind, this study aimed to evaluate the effect that possible alterations, caused by the use of an aerator, could have on the biotic and abiotic factors of a shallow artificial system.

\section{MATERIALS AND METHODS}

\section{Study area and data}

Morphological characteristics of fish pond $\left(21^{\circ} 15^{\prime} \mathrm{S} ; 48^{\circ} 18^{\prime} \mathrm{W}\right)$ are shown in Table 1 and Fig. 1 shows the fish pond bathymetric map.

The fish pond contained adult Ctenophargodon idella (grass carp), Piaractus mesopotamicus (pacu), Colossoma macropomum (tambaqui), Brycon orbignyanus (piracanjuba), Pseudoplatystoma coruscans (pintado), Brycon cephalus (matrinchã) and Prochilodus scropha (curimbatá), totaling 300 fish. The fish were fed daily with $27 \%$ crude protein $(20 \mathrm{~kg} / \mathrm{d})$.

The aerator used was a propeller diffuser aerator with a $2 \mathrm{CV}, 1150 \mathrm{rpm}$ motor and with a $9 \mathrm{~m}$ depth and $23 \mathrm{~m}$ influence zone (Fig. 2).

The water samples were all collected at the surface, with a Van Dorn botlle (5L). The samples were taken, over is a day period, at 09:00 $\mathrm{hr}$, at three different locations delimited for sample taking: $\mathrm{P}_{1}, \mathrm{P}_{2}$ and $\mathrm{P}_{3}$, respectively located at 5, 10 and 23 meters of distance from the aerator (Fig. 1). Of the 15 days, 5 days were without aeration (WA), 5 days were during aeration (DA) and 5 days were after the use of the aerator (AA) to verify the influence of water movement caused by aeration on the water quality.

The limnological characteristics that were analysed are shown in Table 2.

The phytoplanktonics organisms counts were made using a Sedgewick Rafter chamber $(1 \mathrm{~mL})$ in a Leica WD microscope with an amplification of $100 \mathrm{X}$. Filament genus were considered, counting the number of cells per filament, colonies and unicellular organisms as one individual. The density data were expressed as the number of individuals per square meter and as an abundance percentage. 


\section{Data analysis}

An analysis of hierarchical variance (Nested ANOVA) was applied to the nutrient data (Sokal \& Rohlf, 1981), comparing periods without aeration (WA), during aeration (DA) and after the use of the aerator (AA). For the other physical and chemical parameters of water, a variance analysis was first used considering the different points where samples were taken $\left(\mathrm{P}_{1}, \mathrm{P}_{2}, \mathrm{P}_{3}\right)$ and the periods of aerator use (WA, DA, AA) and, afterwards, an LSD test (Least Square Differences) was used to detect significant differences between the mean values (Sokal \& Rohlf, 1981).

A non parametric Friedman test (Campos, 1983) was also applied to test the phytoplanktonic diversity during the various stages of treatment, considering the mean value of the distances per treatment (values in Table 6).

\section{RESULTS AND DISCUSSION}

Aeration is not new to aquaculture, but over the past few years interest in this process has increased tremendously. Aeration is widely used in fish culture and many types of aerators have been tested for effectiveness.

The aerator used was a propeller diffuser aerator, sometimes referred to as propeller-aspirator pumps, consist of a rotating hollow shaft attached to an electric motor, and releases air into turbulent water created by an impeller. It is more suitable for small ponds than others types of aerators.

Although oxygenation is the most important of aerators, water movement caused by aerators is beneficial. Circulation of water during aeration moves oxygenated water away from the aerator to other parts of the pond, and it effects thermal

TABLE 1

Morphological characteristics of the fish pond.

\begin{tabular}{l}
\hline Variable \\
Surface area \\
Maximum depth \\
Mean depth \\
Volume \\
Water renewal time (mean) \\
\hline
\end{tabular}

\begin{tabular}{rc}
\hline Mean & Units \\
$2,305.67$ & $\mathrm{~m}_{2}$ \\
1.7 & $\mathrm{~m}$ \\
1.47 & $\mathrm{~m}$ \\
$3,396.8$ & $\mathrm{~m}_{3}$ \\
27.0 & days \\
\hline
\end{tabular}

TABLE 2

Limnological characteristics analysed.

\begin{tabular}{l}
\hline Limnological Characteristics \\
Temperature \\
$\mathrm{pH}$ \\
Electrical Conductivity \\
Water Transparency \\
Dissolved Oxygen \\
Total Alkalinity and $\mathrm{CO}_{2}$ \\
Ammonia \\
Nitrite and Nitrate \\
Total Phosphorus and Orthophosphate \\
Chlorophyll a
\end{tabular}

Methods
Corning PS 16 thermometer
Corning PS $15 \mathrm{pH}$ meter
Corning PS 17 conductivity meter
Secchi disk
Winkler method Golterman et al.(1978)
Mackereth et al. (1978)
Koroleff (1976)
Golterman et al. (1978)
Golterman et al. (1978)
Nush (1980)


and chemical destratification. Water movement created by an aerator helps maintain high oxygen transfer efficiency, because the freshly oxygenated water is propelled away from the aerator and replaced by water of lower dissolved oxygen concentration. Water currents have a negative effect by increasing oxygen consumption of fish as they are forced to expend more energy (Boyd \& Watten, 1989).

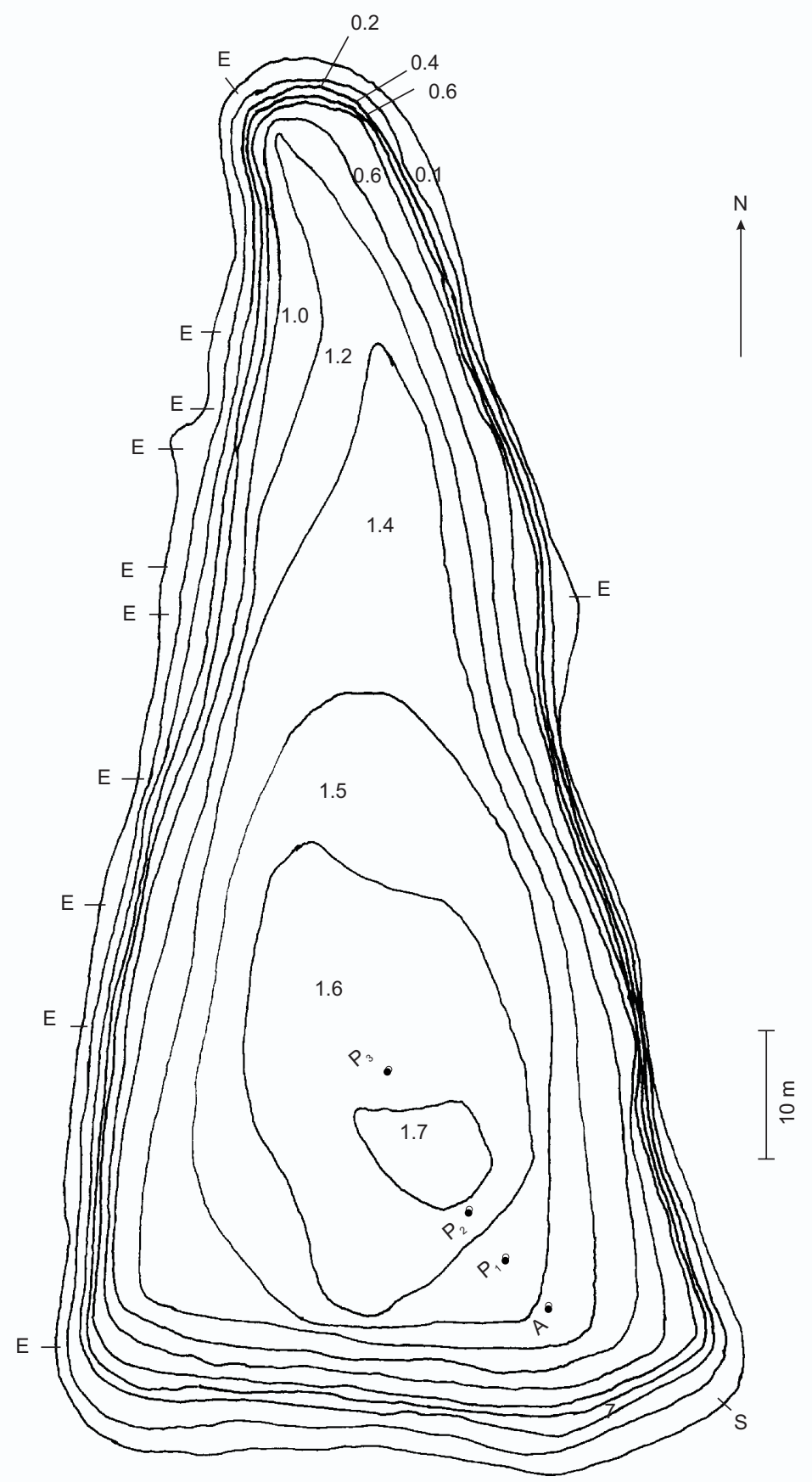

Fig. 1 - Bathymetric map of the pond studied, including location of the aerator (A) and the different sample taking points $\left(\mathrm{P}_{1}, \mathrm{P}_{2}, \mathrm{P}_{3}\right)$. 


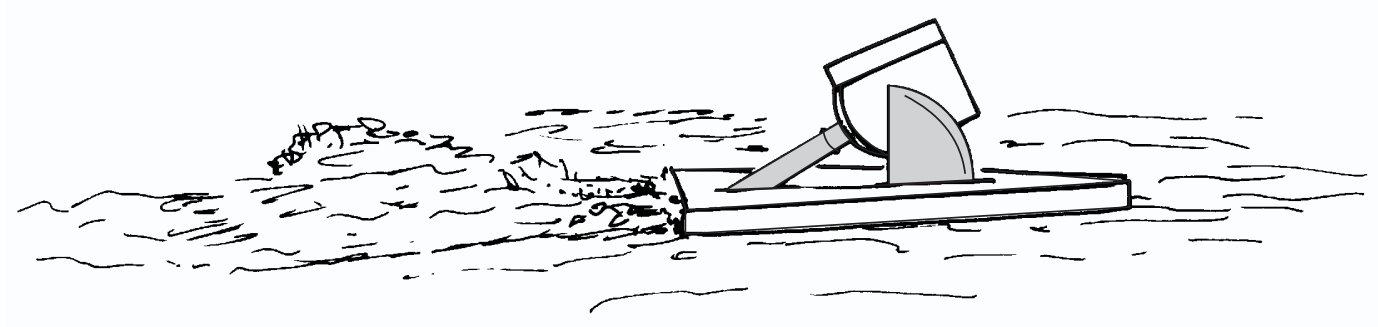

Fig. 2 - Side view of the type of aerator used.

The limnological characteristics studied did not show significant differences $(\mathrm{P}>0.05)$ when comparing the distances of different sample taking points before (WA), during (DA) and after the use of the aerator (AA).

Dissolved oxygen showed an increase in concentration after the use of the aerator, going from a value of 2.13 to $4.74 \mathrm{mg} / \mathrm{L}$ up to 3.19 to $5.53 \mathrm{mg} / \mathrm{L}$ (Table 3), as a result of the mechanical input of air into the system.

The temperature suffered as a direct influence of the aerator (Table 3 ), with significant differences $(\mathrm{P}<0.05)$ between the three sample taking periods (without aerator WA, during aeration DA, and after the use of the aerator AA).

This occurs in shallow artificial systems, such as fish ponds and cultivation tanks, because any movement in the water due to local climatic conditions, or even mechanical agitation, quickly break stratification the temperature gradient (SipaúbaTavares et al., 1994).

Secchi transparency directly related to the phytoplanktonic biomass. Probably, the slight increase in the transparency of water after the use of the aerator could be associated to the intense movement of the water, promoting a greater distribution of the suspended material. This occurred mainly at $\mathrm{P}_{1}$, the closest sample point to the aerator (Table 3), showing significant differences $(\mathrm{P}<0.05)$ when comparing the three sample taking periods (WA, DA and AA) (Table 4).

In cultivation systems, daily feeding as a direct source of nutrients in the environment and residence time, are normally responsible for conductivity concentrations. Conductivity did not show significant differences $(\mathrm{P}>0.05)$ for the three different periods of sample taking (WA, DA and AA), showing some change during the period that the aerator was not functioning (Tables 3 and 4).
Normally, the $\mathrm{pH}$ in cultivation systems is directly related to the forms of inorganic carbon in the environment. The $\mathrm{pH}$ held its alkalinity during all the period studied (Table 3), showing significant differences $(\mathrm{P}<0.05)$ during the period with the aerator functioning when compared to the other two periods, without and after the use of the aerator (Table 4).

Among the inorganic carbon forms, bicarbonate was dominant because of the alkalinity predominance in the system (Table 3 ). The mechanical agitation provoked by the aerator promoted a slight increase in bicarbonate and in free $\mathrm{CO}_{2}$ which showed significant differences $(\mathrm{P}<0.05)$ when compared to the period without the aerator (Tables 3 and 4) since, in aerobic conditions, the decomposition of organic material frees $\mathrm{CO}_{2}$ to the water column (Cole \& Pace, 1995). The higher concentrations of these two forms of inorganic carbon in the environment, after the use of the aerator could be associated to the $\mathrm{pH}$ of the environment that promotes fast transformation of these two elements in the system. Alkalinity and total $\mathrm{CO}_{2}$ did not show significant differences $(\mathrm{P}>0.05)$ with the introduction of the aerator into the pond.

Yoshida (1996) and Souza (1996), working with different kinds of air pumps and comparing them to systems that agitate water in fish tanks, observed that, in the systems that had artificial aeration, the inorganic carbon values and alkalinity were higher.

The effect of mechanical agitation caused a direct alteration in the concentrations of nutrients, increasing nitrite and orthophosphate and decreasing total phosphorus, ammonia and nitrate. Generally, the nutrients showed significant differences $(\mathrm{P}<0.05)$ when comparing the three sample taking periods (WA, DA and AA), (Tables 3 and 4). 
TABLE 3

Mean variation of limnological characteristics of the fish pond, without aeration (WA), during aeration (DA) and after the use of an aerator (AA) at the 3 sample taking points $\left(P_{1}=5 \mathrm{~m} ; P_{2}=10 \mathrm{~m}\right.$ and $\left.P_{3}=23 \mathrm{~m}\right)$.

\begin{tabular}{|c|c|c|c|c|c|c|c|c|c|c|}
\hline \multirow{2}{*}{$\begin{array}{l}\text { Limnological } \\
\text { Characteristics }\end{array}$} & \multicolumn{3}{|c|}{ WA } & \multicolumn{3}{|c|}{ DA } & \multicolumn{3}{|c|}{$\mathbf{A A}$} & \multirow[t]{2}{*}{ Units } \\
\hline & $\mathrm{P}_{1}$ & $\mathrm{P}_{2}$ & $\mathrm{P}_{3}$ & $\mathrm{P}_{1}$ & $\mathrm{P}_{2}$ & $\mathrm{P}_{3}$ & $\mathrm{P}_{1}$ & $\mathrm{P}_{2}$ & $\mathrm{P}_{3}$ & \\
\hline Dissolved Oxygen & 3.48 & 4.03 & 3.54 & 4.60 & 5.11 & 5.01 & 4.73 & 4.99 & 4.56 & $\mathrm{mg} / \mathrm{L}$ \\
\hline Temperature & 25.60 & 25.40 & 25.40 & 21.00 & 21.40 & 21.40 & 20.20 & 20.20 & 20.80 & $0 \mathrm{C}$ \\
\hline $\mathrm{pH}$ & 7.60 & 7.40 & 7.08 & 8.06 & 8.08 & 7.80 & 7.78 & 7.78 & 7.48 & \\
\hline Bicarbonate & 30.70 & 28.17 & 28.98 & 34.60 & 32.68 & 31.76 & 33.20 & 3.00 & 32.57 & $\mathrm{mg} / \mathrm{L}$ \\
\hline Alkalinity & 25.20 & 23.20 & 23.80 & 27.60 & 26.00 & 25.00 & 24.20 & 24.00 & 23.60 & $\mathrm{mg} / \mathrm{LcaCO}_{3}$ \\
\hline Chlorophyll a & 63.61 & 76.45 & 80.00 & 82.86 & 53.57 & 80.63 & 69.20 & 53.00 & 78.68 & $\mu \mathrm{g} / \mathrm{L}$ \\
\hline Total Phosphorus & 54.22 & 30.40 & 25.20 & 31.42 & 24.16 & 35.56 & 53.50 & 41.62 & 37.86 & $\mu \mathrm{g} / \mathrm{L}$ \\
\hline Orthophosphate & 3.66 & 4.00 & 3.66 & 8.82 & 6.32 & 7.20 & 10.70 & 8.88 & 10.20 & $\mu \mathrm{g} / \mathrm{L}$ \\
\hline Ammonia & 28.24 & 18.84 & 23.60 & 8.88 & 5.98 & 3.64 & 5.36 & 8.06 & 9.80 & $\mu \mathrm{g} / \mathrm{L}$ \\
\hline Nitrate & 44.44 & 87.30 & 15.00 & 27.10 & 35.56 & 20.24 & 29.72 & 25.48 & 35.30 & $\mu \mathrm{g} / \mathrm{L}$ \\
\hline
\end{tabular}

TABLE 4

Results from the ANOVA $(P=0.05)$ and the LSD (Least Square Differences) tests $(P=0.05)$ for limnological characteristics, when comparing the distances of the aerator from the sample taking points $\left(P_{1}=5 \mathbf{m}\right.$, $P_{2}=10 \mathrm{~m}$ and $P_{3}=23 \mathrm{~m}$ ), and the period without aeration (WA), during aeration (DA), and after using an aerator (AA).

\begin{tabular}{|c|c|c|c|c|c|c|c|c|c|}
\hline \multirow{2}{*}{$\begin{array}{l}\text { Limnological } \\
\text { Characteristics }\end{array}$} & \multicolumn{2}{|c|}{ ANOVA } & \multicolumn{3}{|c|}{ Mean } & & \multicolumn{2}{|l|}{ LSD } & \multirow[t]{2}{*}{ Units } \\
\hline & $\mathrm{F}_{\mathrm{s}}$ & $\begin{array}{l}\mathrm{F}_{0.05} \\
(2.42) \\
\end{array}$ & WA & DA & AA & & & & \\
\hline Temperature & $105.0^{*}$ & & 25.5 & 21.3 & 20.3 & $\underline{\text { WA }}$ & $\underline{\mathrm{DA}}$ & AA & ${ }^{\circ} \mathrm{C}$ \\
\hline Conductivity & 0.28 & & 50.0 & 50.7 & 49.3 & WA & DA & AA & $\mu . S . \mathrm{cm}^{-1}$ \\
\hline Transparency & $34.71^{*}$ & & 45.0 & 57.0 & 63.3 & AA & DA & WA & $\mathrm{m}$ \\
\hline $\mathrm{pH}$ & $11.45^{*}$ & & 7.3 & 8.0 & 7.7 & $\underline{\mathrm{DA}}$ & $\mathrm{AA}$ & WA & \\
\hline Dissolved Oxygen & $6.78^{*}$ & & 3.7 & 4.9 & 4.8 & $\mathrm{AA}$ & DA & WA & $\mathrm{mg} / \mathrm{L}$ \\
\hline Alkalinity & 1.92 & 3.22 & 24.1 & 26.2 & 24.1 & WA & DA & AA & $\mathrm{mg} / \mathrm{LCaCO}_{3-}$ \\
\hline Bicarbonate & $5.21^{*}$ & & 29.3 & 33.0 & 32.9 & DA & AA & WA & $\mathrm{mg} / \mathrm{L}$ \\
\hline Free $\mathrm{CO}_{2}$ & $4.94^{*}$ & & 2.98 & 0.7 & 1.6 & $\underline{\text { WA }}$ & $\underline{\mathrm{AA}}$ & DA & $\mathrm{mg} / \mathrm{L}$ \\
\hline Total $\mathrm{CO}_{2}$ & 1.18 & & 34.6 & 32.2 & 33.9 & WA & DA & AA & $\mathrm{mg} / \mathrm{L}$ \\
\hline Ammonia & $0.04^{*}$ & & 23.6 & 6.2 & 7.7 & $\underline{\text { WA }}$ & $\mathrm{AA}$ & DA & $\mu \mathrm{g} / \mathrm{L}$ \\
\hline Nitrite & $7.80^{*}$ & & 0.32 & 0.62 & 4.4 & AA & $\mathrm{DA}$ & WA & $\mu \mathrm{g} / \mathrm{L}$ \\
\hline Nitrate & $4.94^{*}$ & & 48.9 & 27.6 & 30.2 & $\underline{\mathrm{WA}}$ & $\mathrm{AA}$ & $\mathrm{DA}$ & $\mu \mathrm{g} / \mathrm{L}$ \\
\hline Total Phosphorus & $0.51^{*}$ & & 36.6 & 30.4 & 44.3 & AA & WA & DA & $\mu \mathrm{g} / \mathrm{L}$ \\
\hline Orthophosphate & $2.27^{*}$ & & 3.8 & 7.5 & 9.9 & $\underline{\mathrm{AA}}$ & DA & WA & $\mu \mathrm{g} / \mathrm{L}$ \\
\hline Chlorophyll a & 1.53 & & 73.4 & 72.4 & 67.0 & $\underline{\mathrm{WA}}$ & DA & $\mathrm{AA}$ & $\mu \mathrm{g} / \mathrm{L}$ \\
\hline
\end{tabular}


Tropical fish pond without aeration the ammonia concentration was $68.4 \%$ higher than fish pond aerated (Matos, 1996).

According to Diab et al. (1992), an important mechanism for nitrogen fixation in the water is nitrification, which can be quickly transformed by intense aeration and water movement.

The increase in the orthophosphate concentrations after mechanical agitation of the water could be associated to the acceleration of organic material decomposition or to the rupture of algae cells caused by the intense water movement that would free phosphorous to the water column, since in most of the points studied it showed an inverse relation to chlorophyll a concentrations.

Chlorophyll a values did not show significant differences $(\mathrm{P}>0.05)$ during the periods before the aerator started functioning, with the aerator functioning and after the use of the aerator (Table 4).

According to Milstein et al. (1995), the abundance of phytoplankton in fish ponds increases in response to the increase of nutrient concentration in the water, mainly because of the constant addition of food in the environment.

The Chlorophyta group dominated the environment with a variation of 70 to $93 \%$ at the three different sample taking points during all of the period studied (Fig. 3). The dominance of this group in fish ponds in the region of the study is common, with fluctuations in the dominance of species as a result of temperature, nutrient availability and turbidity amongst others (Bachion \& Sipaúba-Tavares, 1992).

The water movement caused by the aerator significantly affected $(\mathrm{P}<0.01)$ the phytoplanktonic community (Table 6), inducing an increase in the species present. The Cyanophyta and Chrysophyta groups, especially at the point closest to the aerator, had a tendency to increase progressively with the mechanical agitation of the water (Fig. 3). The species from these groups tend to adapt quickly when changes in the environment occur (Guzkowska \& Gasse, 1990).

The Cyanophyta group are characteristic of eutrophic environments which have high concentrations of nitrate and high temperatures, factors typical of fish cultivation ponds in the region of the study. Consequently, these represented the second most dominant group in the phytoplanktonic community.

On the other hand, the Chrysophyta had a reduced number of individuals since they adapt

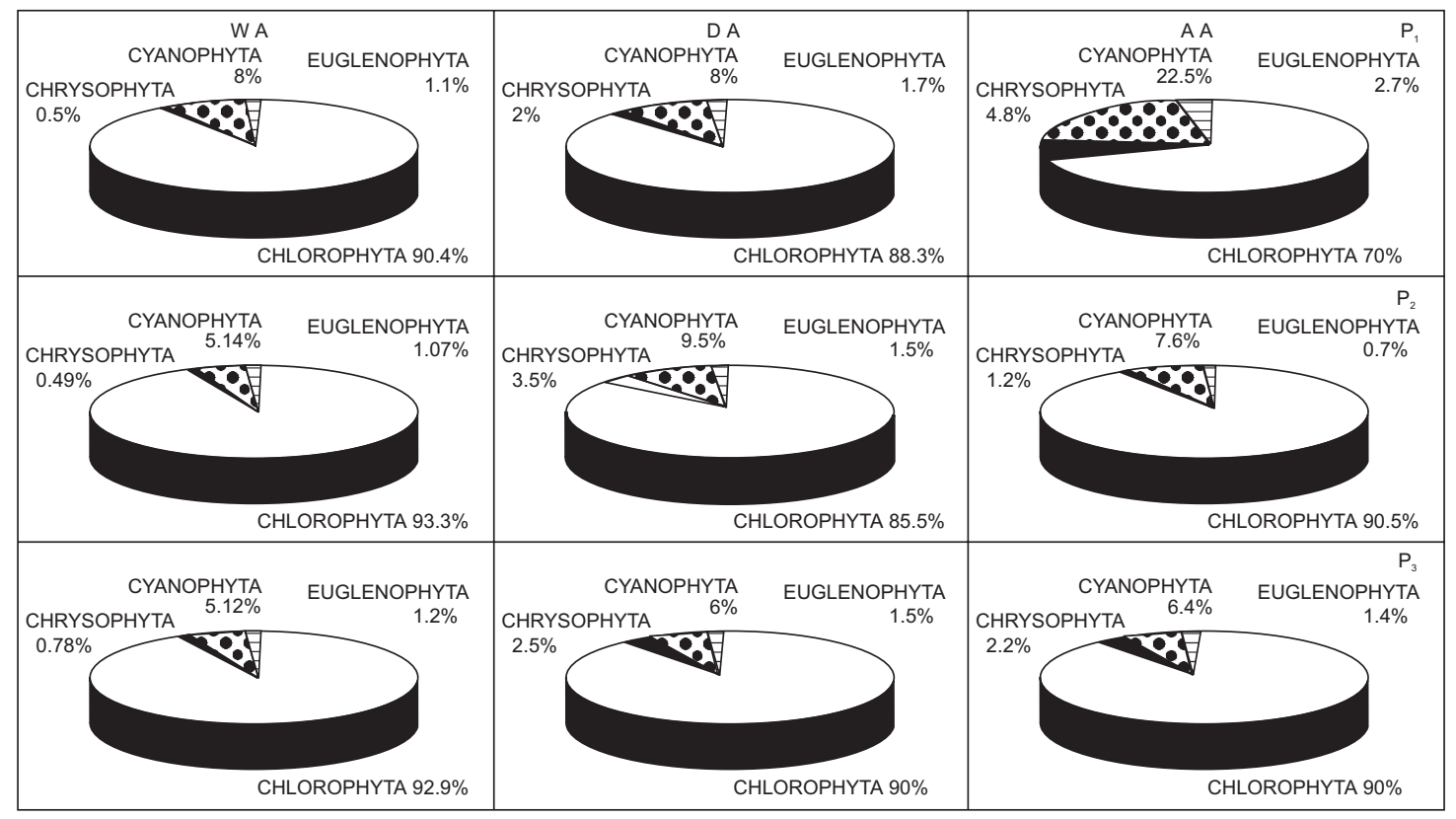

Fig. 3 - Abundance percentage of phytoplanktonic groups at the three sample taking points $\left(\mathrm{P}_{1}=5 \mathrm{~m}, \mathrm{P}_{2}=10 \mathrm{~m}\right.$ and $\mathrm{P}_{3}=23 \mathrm{~m}$ ), without aeration (WA), during aerator (DA) and after the use of the aerator (AA), during the sample taking period. 
better to more stable environments, which is not the case in these cultivation systems, due to management, relatively short residence time and environmental dynamics (Fig. 3).

These two groups were represented mainly by Anabaena flosaquae and Centritractus sp. (Fig. 4).

The Euglenophyta group was represented by only one species, Phacus sp., which is very common in these environments, and the Chrysophyta group by Cryptomonas sp. (Table 5 and Fig.4).

The mechanical aeration caused the appearance of Mougeotia sp., Botryococcus sp. and of Scenedesmus acuminatus at points 2 and 3 . The Chlorophyta showed greater species diversity with Hydrodictyon sp. dominating the environment in the period before the use of the aerator, followed by Chlorella vulgaris which came to dominate the environment after the mechanical agitation of the water (Table 5 and Fig. 4).

With the data obtained from this experiment it was possible to determine that aerators promote an alteration of limnological characteristics, increasing environmental oxygenation but leading to more substantial modifications in some of the biotic and abiotic variables.

After long periods of time these could be capable of causing damage to the environment if aerators are not monitored adequately, especially with regard to the phytoplanktonic community promoting growth of cyanobacteria that have species that present metabolites inhibitory or fatal to fish.

It is difficult to make recommendations on the amount of aeration needed for a pond, or more specifically, one can not readily calculate how much additional fish production can be achieved by the use of a given amount of aeration.

According Matos (1996) in tropical areas the ideal time for aeration should begin at 03:00 to 06:00 $\mathrm{hr}$ in the spring and 00:00 to $06: 00 \mathrm{hr}$ in the summer.

An extensive research effort on water circulation in ponds would be worth while.

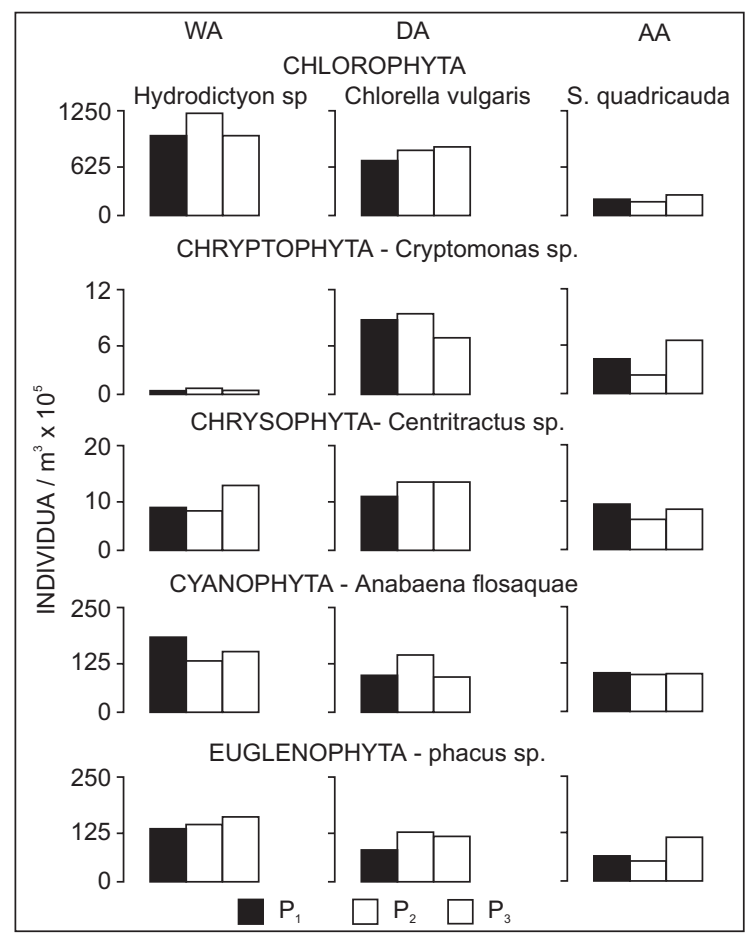

Fig. 4 - Seasonal fluctuation of the most abundant species from each phytoplanktonic group at the three sample taking points $\left(\mathrm{P}_{1}=5 \mathrm{~m}, \mathrm{P}_{2}=10 \mathrm{~m}\right.$ and $\left.\mathrm{P}_{3}=23 \mathrm{~m}\right)$, without aeration (WA), during aeration (DA) and after the use of the aerator (AA), during the sample taking period. 
TABLE 5

Abundance percentage of phytoplanktonic species present at the three sample taking points $\left(P_{1}=5 \mathrm{~m}\right.$, $P_{2}=10 \mathrm{~m}$ and $P_{3}=23 \mathrm{~m}$ ) during the period of time studied without aeration (WA), during aeration (DA) and after using an aerator (AA).

\begin{tabular}{|c|c|c|c|c|c|c|c|c|c|}
\hline Phytoplankton & & $\begin{array}{l}\text { WA } \\
(\%)\end{array}$ & & & $\begin{array}{l}\text { DA } \\
(\%)\end{array}$ & & & $\begin{array}{l}\mathrm{AA} \\
(\%)\end{array}$ & \\
\hline Groups & $\mathrm{P}_{1}$ & $\mathrm{P}_{2}$ & $\mathrm{P}_{3}$ & $P_{1}$ & $\mathrm{P}_{2}$ & $\mathrm{P}_{3}$ & $\mathrm{P}_{1}$ & $\mathrm{P}_{2}$ & $\mathrm{P}_{3}$ \\
\hline \multicolumn{10}{|l|}{ Chlorophyta } \\
\hline Ankistrodesmus sp. & 0.050 & 0.005 & 0.075 & 1.458 & 0.281 & 0.396 & 1.145 & 0.568 & 0.357 \\
\hline Chlorella vulgaris & 24.946 & 23.660 & 23.637 & 57.407 & 56.149 & 63.126 & 11.311 & 70.057 & 65.525 \\
\hline Dictyosphaerium sp. & 0.058 & 0.038 & 0.063 & 0.025 & 0.294 & 0.216 & 0.160 & 3.083 & 0.143 \\
\hline Gloeocystis sp. & 4.767 & 3.880 & 4.664 & 4.629 & 5.445 & 5.588 & 10.604 & 2.880 & 3.049 \\
\hline Hyalotheca sp. & 1.203 & 1.300 & 1.495 & 0.691 & 0.862 & 1.433 & 1.567 & 0.218 & 1.174 \\
\hline Hydrodictyon sp. & 42.765 & 49.770 & 42.335 & 0.215 & 0.296 & 0.244 & 0.679 & 0.182 & 0.649 \\
\hline Mougeotia sp. & 0 & 0 & 0 & 2.424 & 2.795 & 1.860 & 7.305 & 2.570 & 2.336 \\
\hline Oocystis sp. & 0.713 & 0.391 & 0.522 & 6.852 & 3.241 & 2.821 & 4.948 & 1.713 & 2.141 \\
\hline Oedogonium sp. & 1.470 & 1.360 & 1.409 & 1.631 & 1.495 & 1.258 & 2.710 & 0.514 & 1.427 \\
\hline Pediastrum sp. & 0.352 & 0.280 & 0.236 & 0.314 & 0.410 & 0.233 & 0.763 & 0.226 & 0.422 \\
\hline Scenedesmus acuminatus & 0.008 & 0 & 0 & 0.108 & 0.140 & 0.114 & 0.165 & 0.027 & 0.065 \\
\hline Scenedesmus quadricauda & 13.899 & 12.360 & 18.333 & 12.210 & 13.561 & 12.198 & 28.276 & 8.251 & 12.651 \\
\hline Staurastrum sp. & 0.120 & 0.087 & 0.104 & 0.126 & 0.185 & 0.046 & 0.259 & 0.101 & 0.032 \\
\hline Tetraedon sp. & 0.067 & 0.140 & 0.013 & 0.116 & 0.132 & 0.102 & 0.014 & 0.030 & 0.038 \\
\hline \multicolumn{10}{|l|}{ Chryptophyta } \\
\hline Cryptomonas sp. & 0.008 & 0.023 & 0.012 & 0.793 & 0.716 & 0.522 & 0.825 & 0.164 & 0.389 \\
\hline \multicolumn{10}{|l|}{ Chrysophyta } \\
\hline Botryococcus sp. & 0 & 0 & 0 & 0.043 & 0.051 & 0.009 & 0.019 & 0.003 & 0.519 \\
\hline Centritractus sp. & 0.374 & 0.340 & 0.576 & 0.957 & 0.974 & 1.090 & 1.829 & 0.374 & 0.441 \\
\hline Cyclonexis sp. & 0.015 & 0.021 & 0.025 & 0.100 & 0.149 & 0.081 & 0.236 & 0.038 & 0.143 \\
\hline Dinobryon sp. & 0.067 & 0.060 & 0.127 & 0.510 & 1.558 & 0.543 & 1.060 & 0.460 & 0.428 \\
\hline Surirella sp. & 0.031 & 0.070 & 0.055 & 0.342 & 0.556 & 0.595 & 1.119 & 0.312 & 0.480 \\
\hline \multicolumn{10}{|l|}{ Cyanophyta } \\
\hline Anabaena flosaquae & 8.018 & 5.140 & 5.119 & 7.846 & 9.319 & 6.099 & 22.386 & 7.551 & 6.358 \\
\hline Oscillatoria $\mathrm{sp}$. & 0 & 0.005 & 0 & 0 & 0 & 0 & 0.028 & 0 & 0 \\
\hline \multicolumn{10}{|l|}{ Euglenophyta } \\
\hline Phacus sp. & 1.069 & 1.070 & 1.200 & 1.203 & 1.391 & 1.426 & 2.592 & 0.678 & 1.233 \\
\hline
\end{tabular}

TABLE 6

Results from the non parametric Friedman test comparing phytoplankton diversity and the treatments used without aeration (WA), during aeration (DA) and after the use of an aerator (AA).

\begin{tabular}{|c|c|c|c|}
\hline & WA & DA & $\mathbf{A A}$ \\
\hline $\mathrm{R}_{\mathrm{i}}$ & 31 & 55 & 46 \\
\hline$X_{r}^{2}$ & & $13.36^{* *}$ & \\
\hline$X_{r(0,01,2)}^{2}$ & & 9.21 & \\
\hline
\end{tabular}

$\mathrm{R}_{\mathrm{i}}=$ sum of values ranked between treatments, by category of phytoplanktonic species.

$\mathrm{X}_{\mathrm{r}}^{2}=$ value found by applying the Friedman test.

$\mathrm{X}_{0}^{2}=$ observed value.

$* *=\mathrm{P}<0.01$ 
Acknowledgements - The authors thank CNPq (Conselho Nacional de Desenvolvimento Científico e Tecnológico) for their financial support. They would also like to thank Silvia R. L. de Laurentiz and Célia M. D. F. Scorvo for their help in the laboratory and field work.

\section{REFERENCES}

AVNIMELECH, Y., MOZES, N. \& WEBER, B., 1992, Effects of aeration and mixing on nitrogen and organic matter transformations in simulated fish ponds. Aquacultural Engineering, 11: 157-169.

BACHION, M. A. \& SIPAÚBA-TAVARES, L. H., 1992, Estudo da composição das comunidades fitoplanctônicas e zooplanctônicas em dois viveiros de camarão. Acta Limnol. Brasil, 4: 371-353.

BOYD, C. E., 1993, Manejo de viveiros: qualidade de água e condições de solo. Panorama da Aqüicultura, 3: 8-9.

BOYD, C. E. \& WATTEN, B. J., 1989, Aeration systems in aquaculture. Aquatic Sciences, 1: 425-472.

CAMPOS, H., 1983, Estatística experimental não paramétrica. ESALQ/USP, São Paulo,123p.

COLE, J. J. \& PACE, L. M., 1995, Bacterial secondary production in oxic and anoxic freshwaters. Limnol. and Ocean., 40: 1019-1027.

DIAB, S., KOCHBA, M., MIRES, D. \& AVNIMELECH, Y., 1992, Combined intensive-extensive (CIE) pond system. A: inorganic nitrogen transformations. Aquaculture, 101: 33-39.

GOLTERMAN, H. L., CLYMO, R. S. \& OHNSTAD, M. A. M., 1978, Methods for physical \& chemical analysis of fresh water. Blackwell Sci. Publ., London, 213p.

GUZKOWSKA, M. A. J. \& GASSE, F., 1990, The seasonal response of diatom communities to variable water quality in some english urban lakes. Freshwat. Biol., 23: 25164.

HOPKINS, J. S., HAMILTON II, R. D., SANDIFER, P. A., BROWDY, C. L. \& STOKES, A. D., 1993, Effects of water exchange rate on production, water quality, effluent characteristics and nitrogen budgests of intensive shrimp ponds. Jour. World. Aquacul. Soc., 24: 304-20.
KOROLEFF, F., 1976, Determination of nutrients, pp. 117 181. In: K. Grasshof (orgs.), Methods of Seawater Analysis, 300p. Verlag Chemie Wenhein, German.

MACKERETH, F. J. H., HERON, J. \& TALLING, J. F., 1978 , Water Analysis: Some Revised Methods for Limnologists. Freshwater Biological Association Scientific Publication $n^{\mathrm{o}}$ 36, Titus Wilson \& Sons Ltda, Amblesie, 121p.

MATOS, A. C., 1996, Efeitos da aeração e da taxa de renovação de água em policultivo de peixes. Florianópolis, SC, Brasil (Thesis).

MILSTEIN, A., ALKON, A., KARPLUS, I., KOCHBA, M. \& AVNIMELECH, Y., 1995, Combined effects of fertilization rate, manuring and feed pellet aplication on fish performance and water quality in polyculture ponds. Aquaculture Research, 26: 55-65.

NUSH, E. A., 1980, Comparison of different methods for chloropyll and phaeopigments determination. Archi. Hydrobiol., 14: 14-36.

PARKER, N. C. \& SUTTLE, M. A., 1987, Design of air pumps for water circulation and aeration in aquaculture. Aquacultural Engineering, 6: 97-110.

SIPAÚBA-TAVARES, L. H. \& MORENO, S. Q., 1994, Variação dos parâmetros limnológicos em um viveiro de piscicultura nos períodos de seca e chuva. Rev. Unimar, 16: 229-42.

SOKAL, R. R. \& ROHLF, F. J., 1981, Biometry. W. H. Freeman and Company, New York, 123p.

SOUZA, M. L. R. de, 1996, Efeito de sistemas de aeração e densidade de estocagem sobre o desempenho e características de carcaça da tilápia do Nilo (Oreochromis niloticus, Lineaus, 1757). Jaboticabal, SP, Brasil (Thesis).

YOSHIDA, C. E., 1996, A dinâmica dos fatores físicoquímicos em três tanques de piscicultura com renovação contínua, sem renovação da água e aeração artificial. Jaboticabal, SP, Brasil (Thesis). 